\title{
How to Develop True Care: Three Interviews with Nel Noddings
}

In 2011, 2012, and 2016, Masao Yokota, a contributing writer for Japanese language publications, conducted and translated into Japanese three interviews with $\mathrm{Nel}$ Noddings. The first two interviews appeared in Seikyo Shimbun, the daily newspaper for the grassroots lay organization Soka Gakkai, which is based on Nichiren (12221282) Buddhism. Globally, Soka Gakkai International (SGl) has constituent organizations in 192 countries and territories. The third interview appeared in Ushio, a monthly Japanese language magazine for a general audience. Masao and Nel first met at a conference in the early 2000s. When they next met, Masao learned Nel, with her husband Jim, soon would be in Kyoto, Japan. Masao then arranged for them to visit Soka Junior and Senior High Schools in Tokyo.

Providing a backdrop for the interviews is common ground found in the work of education philosophers John Dewey (1859-1952) and Tsunesaburo Makiguchi (18711944). In 1930, Makiguchi founded Soka Gakkai's forerunner, Soka Kyoiku Gakkai, comprised of teachers and educators actively promoting education reform in Japan as advocated in Makiguchi's The System of Value-Creating Pedagogy (1930). To counter an increasingly nationalistic and militaristic curriculum, Makiguchi believed the purpose of education is the lifelong happiness of the student, which he understood to include developing each child's unique personality and capacity to live a socially contributive life. Coinciding with changes in the curriculum, the Japanese government imposed a state religion, using Shinto mythology and emperor worship, promoted nationalism and cracked down on any dissension. Makiguchi staunchly opposed these repressive actions. In 1943, Makiguchi, along with his protégé Josei Toda (1900-1958) were arrested and imprisoned. A year later, Makiguchi died in prison of malnutrition, all the while refusing to compromise his beliefs.

ISSN 2560-8371

DOI: 10.24908/encounters.v20i1.13409

(c) Encounters in Theory and History of Education | 102 
Third Soka Gakkai President Daisaku Ikeda carried forward the legacy of education reform initiated by Makiguchi and Toda. Ikeda established a Soka Schools system comprised of kindergartens, elementary, junior and senior high schools and a university in Japan. Soka University of America opened in Orange County, California, in 2001. Soka kindergartens are operating in Hong Kong, Singapore, Malaysia, South Korea and Brazil. Among several cultural institutions outside Japan, in 1993 lkeda founded the Boston Research Center for the 21st century in Cambridge, Massachusetts, renamed the Ikeda Center for Peace, Learning and Dialogue in 2009.

Nel's interactions with the Ikeda Center have entailed advising the Center's Soka Education Fellows Program, speaking at Center events, and editing Educating Citizens for Global Awareness (2005), developed in collaboration with Teachers College Press. Nel also visited and spoke at Soka University of America in 2006 and again in 2011.

Clarissa Douglass, an independent scholar researching women and power, also participated in and provided support for the interviews conducted at Nel's home in Ocean Grove, New Jersey. The transcripts here have been edited.

\section{February 15, 2011}

Ideally, education enables us to actualize and uncover our potential. Schooling, testing and a rigid curriculum can freeze potential from developing. Please share your thoughts on education for developing individual potential in contrast to only acquiring fixed knowledge, which can dehumanize and use people as a means.

I don't agree with John Dewey on everything. But on education he was fundamentally right that education isn't preparation for life. Education is life itself. Alfred North Whitehead said the same thing before Dewey. The idea is just what you suggested -to continue to grow but not to grow like a cancer. What do we mean by growth? Dewey would say it is growth leading to more healthy growth, not the sort that eventually destroys you. As a teacher, how do you know if you are promoting healthy growth or not? This is what we are up against in American schools right now, because people mistake accumulation of lots of facts and memorized skills for education. This is an important problem and people are not talking enough about it. Young students think they're being educated if they take a string of subjects and get high marks in every one. Maybe they are not being educated. Maybe they're just learning stuff they hand back.

If you talk to high school kids taking so-called hard subjects, many of them are unhappy, feeling stressed. They get no joy out of it. One of our grandchildren went through the International Baccalaureate program. There are good things about that program but way too much is loaded on the students. She finished the high school program and took a year off before going to college because she couldn't bear to go 
through more of this. When you graduate from high school you should be eager, looking forward to going college. What ought to have been a happy event for her was a frightening, deadening possibility. You can't judge education by the number of facts a kid can give you. You have to go for something deeper than that.

Good education encourages questioning. Education focused only on imparting knowledge doesn't allow for questions. Students eventually become bored and less motivated.

Yes. In my book coming out soon titled, Peace Education: How We Come to Love and Hate War (2011), I show as human beings how ambivalent we are about war. On one hand, we say we hate it. On the other hand, as soon as we are into a war, the soldiers are our heroes and flags fly. In most schools we can't even talk about these things. At end of the book, I ask readers to think about what l've laid out and what is reasonable. It is theoretically sound but I don't have much hope it will ever be done.

You and I, as a Japanese and an American, can talk about these things. If we talk long enough, probably we both will break down in tears over the awful things our people have done to one another. Yet in a high school classroom, where it is so important for kids to hear these things, we don't talk about them.

During Makiguchi's time, education in Japan moved toward testing and examinations, aimed at securing good employment and social status. Challenging this, Makiguchi developed his pedagogy for children's happiness, for developing their character.

Going along with this is the growth of specialization. This is not education. Liberal arts have deteriorated to a set of highly specific subjects with no connections to each other. Somehow those connections have to be made. For example, I wish mathematics teachers would spend time on the Pythagoreans, the mystery of numbers and their focus on the number "1." Or be asking should we look at the universe as "one" or "many?" Of course, there is a lot involved here but you don't find math teachers saying anything like that. Or how about Newton's attempt to bring Bible chronology into agreement with historical chronology. Imagine that. Or we have wonderful numbers like the Golden Mean or even the logic and illogic in Lewis Carroll's Alice in Wonderland. There is so much wonderful stuff, but it's not discussed in math classes.

Makiguchi encouraged students to ask questions. The curriculum said the emperor was divine, a god. Makiguchi said, "No, he is a human being. We have to 


\section{question everything, including the emperor." Makiguchi was eventually arrested} as a thought criminal.

Even just informing kids about certain opinions is an acute problem in the United States right now. Some people say students shouldn't hear about this stuff. There are influential people in Texas who want to eliminate Thomas Jefferson from the curriculum because he advocated separation of church and state. You can't eliminate Thomas Jefferson from the curriculum, but they did eliminate James Madison, the next president, because he was not a believer. It is very difficult to come to grips with these things.

\section{In Japan many people appreciate Emerson, Thoreau, Whitman, William James, Dewey and Jane Addams. Has the US created opportunities to fully recognize and appreciate their work and thinking?}

No, but we have to keep trying. When talking about democracy, I talk about Whitmanesque democracy, which emphasizes interdependence and relationships, where we have respect for every form of honest work, where we realize not one of us could survive without other people. Many agree with this but even today in some circles if Whitman is mentioned, they are likely to say he was homosexual. We don't know. He might have been. So what? This is the thinking we are up against - these tight boundaries where you better believe this way or you are not one of us. Of course, this is what education should break down, these barriers so you can see beyond your own walls.

\section{It's great that you bring Whitman into your discussion of democracy.}

If you think about it, the world is so full of possibility and people keep knocking it down, trying to make it all one way. There are problems with the standardization movement, teaching everybody exactly the same stuff, exactly the same way, expecting the same results. Part of the problem is good intentions. Some of my colleagues think the intentions are not good, that some people want to get rid of public education, privatize and make money out it. They may be right. They argue we live in a country that has abused its minorities for a long time and it is high time we give minorities the same education we give privileged, white kids. If you're a decent person, you can't argue against that. Does that mean everybody gets exactly the same education? That's how they have promoted it.

This is asking what does an educated person look like? Then fill it out in detail. It's one thing to say an educated person is open-minded, knows how to investigate, engages in dialogue and critical thinking. I don't have a problem with any of that. But when you go on to say an educated person knows the quadratic equation, can tell you 
dates of WWI, etc. in the name of helping minorities, we're doing the opposite because we are telling a lie about what education is.

I'm fortunate to have a little more credibility than many of my colleagues because I spent so many years teaching in public schools. They know I am not speaking from some odd, abstract point of view. Say you're teaching geometry. Today, teachers are told exactly what children need to know, what to teach and here's how to do it. When I taught geometry, I tried out all kinds of things. If only one or two students picked up on it, that was alright. I wasn't going to give a test on that. I remember one student wanted to know what geometry had to do with God. That was wonderful for him to have that interest. We could talk a bit about geometry and religion, mathematics and religion and the wonderful history there. Now I wasn't going to give a test on it and the others weren't interested at all. Also, I had many students interested in mathematics and music. Of course, you will encourage that but you aren't going to force everyone to learn about mathematics and music. That's what we're losing - where teachers can present possibilities and say, "You might want to read this or try that." You can't make everybody the same. That's ridiculous.

Does this standardization come from wanting a sense of security? Is the thinking if everyone looks and acts the same, somehow you will be secure? If everyone looks and acts the same, however, there is no room for growth. This is also a problem in religion. For example, there are religious traditions and communities contributing to humanizing people and there are dehumanizing ideologies based on fixed ideas or dogma.

Often those differences exist within religions, which is important for people to understand. For example, there are some awful features of God in the Old Testament. If he was a character in a novel, you would say God is the villain. We should be able to talk about that and ask is there another side there? Is there something beautiful or inspiring there? Some of the most beautiful statements on peace anywhere are in Buddhism but have Buddhists nations engaged in warfare? Yes, there has been warping of that too. The steps leading to enlightenment are being used instead for military discipline. You are hard pressed in schools to be able to discuss this, even though you are trying hard to show both sides of it.

Harvey Cox published The Future of Faith (2010) in which he categorizes faith into three ages: the age of faith when people still connect with Jesus's spirit or behavior. Then comes the age of belief, during which he says the Roman Empire highjacked Christianity, with the teachings being used to control people. This 
lasted until the 20th century. He writes we now are in the age of the spirit, which is more universal, more humanistic. The focus isn't on only just one religion.

This reminds me of how Paul Tillich described the ages. If you look at these side by side, you see something to be encouraged about and something to worry about. In his short, lovely book The Courage to Be (1952), Tillich describes three big ages and described the age we are living in as an age of "anxiety of meaninglessness." His argument is convincing. Since most people no longer simply accept what the Church tells them, in the Western world we're looking at a rise of anxiety of meaninglessness. Who am I? What is the meaning of life? What kind of life should I live?

l've been inspired by the Indian poet and philosopher Rabindranath Tagore. In The Religion of Man (1931) he argues that nature, poetry and experience are foundational for developing humanistic religion.

I am reminded of the marine biologist encouraging us to look at ourselves in relation to the whole earth, to all living creatures and to the earth itself. This takes us away from our notion of being the center of things to a much more relational perspective. He even criticizes some animal rights people. He does agree we shouldn't be cruel of course. But this viewpoint is too limited if we forget we are in relationship not only with sentient animals but with oysters and horseshoe crabs, the sand and the water. We ought to be more open-minded.

\section{Would you say you are a religious person or non-religious person?}

I am non-religious in the sense of not belonging to any sect and I am religious in the sense I can be carried away by a sunrise or by a fish glistening in the water, among many other things.

Why do you feel religious when you see the rising sun or when you feel the oneness of nature? Is it a sense of wonder?

I don't know why but I do. Part of it is a sense of wonder. You feel something you wouldn't want to live without. I get the same experience in the garden in the spring.

\section{January 18, 2012}

Your recent book is Peace Education: How We Come to Love and Hate War. Please share a bit about this project.

At the beginning of the book I explain I was intending to do something somewhat different, but when I discovered there are mountains of books on peace, I changed my 
mind. Many of these books are wonderful, no question about that. But I said, "What is the one thing we are not doing in schools?" There are many things we are not doing. In particular we are not teaching anything about the psychology of war. I read Jonathan Glover's excellent book Humanity: A Moral History of the Twentieth Century (2000). Glover says we can't do anything about the technology that has now gone beyond us and so we have to turn to psychology. That's exactly right. Getting hold of the psychology is the key to managing the technology. That is what I decided to concentrate on. From beginning to end, I was looking at the ambivalence, the ambiguities and how we can say and mean one thing one day and then a few days later say and mean the opposite.

\section{What do you think is the essence of human nature?}

One thing we have to understand is human nature is partly a product of evolution and even more a product of culture. Our emotions are partly innate and partly influenced by not only the culture in general but by events. If we are not prepared, then we are easily manipulated. That is a primary point in the book. We should help students understand how they are manipulated. This should be one of the basic ideas of critical thinking.

\section{You mentioned evolution. It seems many focus on only part of Darwin's theory, survival of the fittest. Some scholars say we have ignored Darwin's ideas about love and caring.}

In my book, The Maternal Factor (2010), I point out the maternal instinct is part of our biological nature and so let's look at development of morality through that line of events. Until recently this hasn't been done. Putting aside religion for the moment, traditional philosophers have looked at it mainly from the perspective of self-interest. I don't mean selfishness. Men have sensibly said, "How should I treat this other guy if I want to be treated right?" Religion backed that up saying, "Do unto others as you would have them do unto you." I look at it from the mother's perspective, "Do unto others as they would have done unto them," which means you have to think about what the other is feeling. Not just how I would feel in that situation but how is this other person really feeling? That is a major difference.

I am gratified to see how much care ethics has grown. Many people are now interested in it, thinking and writing about it and raising questions. There is still an attitude of projecting oneself into another's situation, asking "How would I be in that situation?" This is empathy, what we called sympathy. Instead, we need to use Simone Weil's question, "What are you going through?" Ask the other, then you listen. You receive. You don't start from your own perspective. 
Especially in the West, we have tended to see humans as separate from nature and therefore humans should control nature. The Buddhist view is we are part of nature. This is a big difference.

Right, I totally agree. I recently finished a chapter for a book on Paulo Friere (Paulo Freire's Intellectual Roots: Toward Historicity in Praxis, 2013). The title is "Friere, Buber, and Care Ethics on Dialogue in Teaching." For Friere, Buber and care ethics, it's important to locate human beings in the world, as part of the world, none of that spectator theory business. There are a lot of commonalities. In my recent visit to China, I found a lot of interest in care ethics, more so than here in the US.

If we develop this idea of humans as integral to nature, would we become less aggressive? If we see ourselves in nature, can we learn how to work with others or how to appreciate others?

As I was getting ready to write The Maternal Factor, I was reading a lot of the interesting work being done now on evolution. Looking at animal behavior, for example, there certainly is maternal instinct, affection, things we think of as our own. This underscores that we are animals and we've developed something very special. But we have to make choices on what we are going to develop and what we are going to get over.

The home and the family can be a place for creating peacemakers. How did you raise your own family? You have five biological children and five adopted children. You and Jim produced a beautiful environment for the children to work together and respect each other.

You have to when you've got that many kids! We were very organized. Some think organization and creativity are in opposition. They are not. Jim of course is an engineer. This may sound silly, but we were both influenced by the book Cheaper by the Dozen (Frank B. Gilbreth, Jr. and Ernestine Gilbreth Carey, 1948). Their story intrigued us and we wanted the family to be organized. That was the only way we could manage with so many kids. For example, in addition to his engineering job, at one time Jim owned three laundromats. He did all the repairs on the machines. A couple of the kids would always go with him to collect the money and make minor repairs. Every 50-cent piece was put away for family vacations and trips. The kids knew this. In spring we took the whole family camping in Florida. Our family car was an eight door Aerobus. It was quite incredible. A lot of planning went into those trips and the kids participated. Of course, they got a little pay for their work as well too.

We always had meals together. That was important. People say they're too busy to eat together now. You couldn't be much busier than we were. Everyone has to eat, so why not have a specific time? Unless something extraordinary happened, we ate 
together. Even now the house is usually full all through the summer with kids and grandchildren. Everybody knows we have dinner together. Unless they have a good excuse, they are expected to be here for the meal. It's an opportunity to check up on them. Find out what's been going on in the day, see how people are feeling, see if there is a problem.

\section{You had five children of your own. Why did you decide to have an even bigger family?}

We always wanted a lot of kids. We were sort of embarrassed when the fifth one came along. She was not planned. We were worried about our contribution to over population. But we wanted to have more kids so we decided we would adopt them. That was part of it. The other part was Jim had spent time in Korea, just before the Korean War. He went into the army when he was 17 . Almost every boy in our graduating class went in because they could get the Gl Bill and there was no war. They were relieving guys who had been in the war. Jim worked with another person to form the first Boy Scouts troop in Seoul and became drawn to the people he had worked with there. I was a big fan of Pearl Buck. She was much underestimated. She received the Nobel Prize and a lot of the male writers scoffed at it. Some of her books are impressive. In particular, she wrote interesting biographies of her mother, The Exile (1936), and her father, Fighting Angel (1936).

With these two influences, we decided to adopt. The children's fathers were Americans and our country didn't want to have anything to do with them. We are still ashamed of the attitude our country took toward these kids. The Koreans should be ashamed too. They didn't want anything to do with these children because of pure race and all that stuff. What was to become of these kids? That's where the Pearl Buck Foundation pitched in and helped. She started an adoption agency, Welcome House, in Doylestown, Pennsylvania, where we went to start the adoption procedure. The US would allow only two visas for Asian adoptions. We wound up with three because one child was already in this country. Another family had brought him in and then decided they didn't want him. That's how we wound up with three.

\section{In a way you inadvertently conducted an experiment since you had five biological and five adopted children. Everyone had to learn to treat everyone as equal.}

The other two were not Korean. They just came along and joined up with the family. The oldest one is actually a cousin of mine whose family situation was a mess. We took her on when she was fourteen, a sophomore in high school. 


\section{Were there behavioral differences between your biological children and your adopted children?}

Of course, in a big family like that you have sibling rivalries, kids vying with each other for things. What fascinated Jim and me was oddly enough, we never saw rivalries along natural-adopted lines. Our natural kids never seemed to resent the other kids and the other kids never said, "Well, you love them better than us." I never heard any of that. But that doesn't mean we weren't closer to some than to others. Those things are just there and you accept them. You don't discriminate on privileges, money or things like that.

\section{Did you see any cultural differences among those adopted children?}

Yes, with the oldest boy, because he still had relatives in Korea. He was 12 when he came to this country. He had it very rough, being rejected by his first family. He wanted and we encouraged him to maintain connections with his Korean family. We did that with all the adopted kids. The first girl came from a troubled family and we helped her patch things up with her biological mother. Similarly, with the second girl who came along. Many adoptive parents are afraid their kids will rejoin their biological families. We were not afraid of that. The younger brother of the oldest wasn't interested and the other boy, who was our first adopted child, had no interest whatsoever in their biological families. My guess is the more open you are about it, the easier the whole thing will go. That isn't to say it was a cinch.

The oldest finished high school and then had a heavy year of college. He wasn't interested academically and so decided to join the Air Force on condition they would send him to Korea. They did and he had an opportunity to visit his natural mother, who was still alive at the time, and his cousins. He came home depressed, saying "When I'm in America, I feel like a Korean. When I'm in Korea, I feel like an American." I will never forget that. There isn't anything you can do to relieve that. It is just the way our cultures are. He and his wife from an arranged marriage built up solid friendships in the Korean American community in California. This is so different from the other two Korean American boys. They didn't want part of anything like that. It's fun, all that difference!

You and Jim are a wonderful example of how we should learn from, respect and care for each other. This is the atmosphere for creating peace. The relationship between husband and wife can be a resource for creating trust and peace or the opposite. What is your secret?

Friendship. Friendship is the secret. Of course, we do love each other but we regard liking each other as even more important. We like to quote from "Shenandoah," a movie in which Jimmy Stewart portrays a father of several, grown children. A young 
man comes to ask if he could marry the daughter. They talk, get along well. The father asks something and the young suitor says, "I really love her." Jimmy Stewart's character says, "I know you love her but do you like her?" Jim and I never forgot that. It is so important to enjoy being together, sharing things. We were classmates in high school and we've been best friends since age 14 .

Sometimes our notions of love become wrapped up with a sense of self possession and if it doesn't work, it's easy for love to turn into hatred. Friendship doesn't have that kind of element.

I think it's more solid. We kid a lot about these things. Do you remember "Fiddler on the Roof?" Another movie, also a Broadway show, about a Jewish community. They were poor, struggling to make a living. They couple said something about liking each other. And the husband would keep asking, "But do you love me?" because the wife nagged him quite a bit. Both are important of course, but the liking, the friendship, creates a solid foundation.

There is widespread concern about homelessness. You have written about this. We have to think more broadly and deeply about the meaning of being homeless.

Yes. In my writing, I was more concerned with having people think about what it means to be homeless in this country. Many say, "Well, get a job. Apply for a job." When you're homeless, how are you going to do that? For example, if you apply for a job, there is no way for them to contact you. This was part of my concern. I'm also concerned on an international level of what it means to be homeless. I use the Palestinian example because the studies are heart wrenching. Sociologists found the first generation longed for an actual place -- that yard, those trees, these neighbors. The second generation was separated from that actual place. They were longing for the memories told by their parents. For the third generation, there was nothing personal they could remember. They weren't attached to an actual place so it then became political. Historically, often groups in power have lightly decided where to move people, where they will live. Decisions are made with a lack of understanding.

Many speak about the role of religion in creating peace. Conversely, religion often plays a role in creating violence, initiating and supporting war. The teaching itself is peaceful but because of our interpretation, we use it to justify war. How do we overcome this?

All great religions have lovely messages of peace and compassion. That's great. But alongside of that, each one as a message of violence, war and cruelty. There is a long list of nonsense that invades every religion. Intelligent participants put that all aside. I 
would like to see an intelligent approach to teaching religion but I don't think it's going to happen. It's just too hard.

My recent interviews have focused on humanistic religion. Ikeda encourages us to focus on behavior, not just the teaching. If we only stick to doctrine, it's easy to become dogmatic. But if we focus on moral behavior, then we have a source...

As long as it doesn't become authoritarian. That is one of the problems I have with character education as it often appears in American schools, where you are teaching virtues. That is highly questionable. Socrates raised the question. I don't think we can teach the virtues but teaching must have something to do with it. This opens a whole way of thinking about it. Part of it is teaching by example. But when you become authoritarian, saying "Do this or else," with a list of punishments waiting - that is not the way to go.

Motivation determines everything. In a conversation with a Dewey scholar, Ikeda weighed both religion and education equally in terms of importance.

Martin Buber did too. Buber said education is the education of character. He didn't mean the character education we see now in schools with all these specific rules and penalties, for example zero tolerance rules. This is counter-productive, because you want the students to feel free to talk to you. If a penalty is involved, they are not likely to talk with you.

During WW II, authoritarian politicians and even religious figures misled the Japanese. One of Ikeda's concerns is we could become victim again to authoritarianism. In our large lay organization, the focus is on dialogue and small discussion meetings.

Part of learning is acknowledging what we've done wrong. The US has had that problem. Japan too has had that problem, facing up to things they wished hadn't happened. But those things did happen. So, we have to ask how can we be sure they won't happen again. Here's another thing we have to remember. Academics are different from other people - not entirely different but in many ways different - because of the emphasis on thinking, dialogue and talking things through. One of the big interests I found in China was talk about the similarities between Confucianism and care ethics. 
Is there an aspect to Confucianism that can veer toward authoritarianism? Or of being bound by the culture?

Sure. Confucianism and care ethics both deemphasize big general rules, big general principles. It's not that we reject them or say they are bad but they aren't any help when you are in a tight situation. Take for example "Do not steal." We all agree on that. But as I've told many audiences, if my children are starving and I have an opportunity to steal, you can bet I would do it. I would feel immoral if I didn't. Let my kid starve rather than do this? You can go down the whole list of big principles and you find when you are in a tight situation, they don't help very much. Another example is "Do not kill," but if your government tells you to kill, that isn't going to help you at all.

Where care ethics leaves this open and keeps relying on the interpersonal relation and dialogue, in contrast Confucianists come up with rules governing particular situations. Father to son, brother to brother and sister to mother. This is a major difference between care ethics and Confucianism. Interestingly, Chinese feminists are moving in this direction because they have never been allowed to come up with these rules. It's the guys who invented all the rules. We're now realizing that's probably not the best way to go.

When Ikeda spoke at Teacher's College in 1996, he shared three requirements for being a global citizen. I'm interested in how these can be applied in creating peace. He said one condition for being a global citizen is the wisdom to perceive the interconnectedness of all life, as opposed to seeing separation and isolation, which can become a cause for fear and even aggression.

Right. That's a major point in my upcoming book, Education and Democracy in the $21^{\text {st }}$ Century [2013]. Interdependence is a goal. We have to recognize this in education. Educators all over the world now are saying cooperation is more important than competition. Moving away from individualism toward an understanding of interdependence, beyond the human to the ecological realm, which is so important. The basis of ecological thinking is looking at the whole community, not just one individual or species. This should be primary in 21 st century education.

The message of interrelatedness is to be responsible to other people and other species. Ikeda's next point is to develop the courage not to deny differences, rather respect and understand different cultures - a recognition, an appreciation of difference.

This forms the foundation for peace. Actually, John Dewey made this point. Dewey said when you've got severe disagreements or interpersonal problems, you should talk but not about those problems. Rather start somewhere else. You talk about other things until it becomes unthinkable for you to do real harm to this "other." At that point 
then talk about your conflicts, because you aren't going to hurt each other. This is such good advice. Instead of rushing to solve the problem, start first by trying to understand each other.

When you visited a Soka School in Japan, the students sang "America the Beautiful" in English. Following this, you remarked when you were a teenager, Americans talked in a deplorable, vile way about the Japanese. At the same time, Japanese were speaking the same way about people in the US. In contrast, you observed at the Soka School, students truly wanting to appreciate and praise the beauty of America.

Jim and were very touched. I'm not easily moved to tears but I came close then. How stupid human beings are! Here you've got these lovely children singing "America the Beautiful." Fifty, sixty years before we would have been killing each other. The students were darling. I did exercise a little influence when we were out front, taking pictures. The boys crowded to the front. The girls were pushed to the side. Jim and I both said, "Wait a minute." I brought the girls to either side of me and we put our arms around each other.

Ikeda's third point is compassion, having imaginative empathy, even for those living far away. It's important to develop compassion for people who are suffering, even if we don't see them. Please share your understanding of the real meaning of care?

I distinguish between "caring for" and "caring about." Unless we have direct contact, we are not in position to "care for." But we should develop this sense of "caring about." Without direct contact this can go off track. Americans often decide what is good for other people, trying to solve problems from a distance, saying, "These poor folks, here's what you need. Here's what you should do." But we don't know what they need because we haven't talked to them. That is a danger of "caring about." Still, "caring about" sows the foundation for a sense of justice. Clearly, it's impossible for any human being or group to care for everyone because that requires direct connection. But you can care about and work to build situations so "caring for" can flourish.

We make these mistakes all the time. Several decades ago following a bad earthquake, the US rushed clothing and food to the area when what the people desperately needed was building supplies. We didn't go and ask them what they needed. We just decided what they needed and dumped it off. We do somewhat better now because communications are better and swifter. 


\section{Do you have more examples of caring for contrasted with caring about?}

Everything we do person-to-person should be characterized by caring. This is true whether it's a stranger or someone we regularly meet and applies most obviously to situations in which we actually encounter others. It's foundational in teaching, in forming friendships, in neighborhoods. Then there is what it does to supply the foundation of our thinking for when we're trying to relate to people at a distance, recognizing we cannot do what we would do if we were face to face. Then asking what can we do to build the conditions under which caring can flourish.

\section{You said we need to know what others really need. For this, we have to be involved in dialogue, conversations.}

Yes. We've made so many mistakes along these lines. While I was in graduate school at Stanford, many students were gung-ho to do something about the exploitation of coffee farmers in Brazil. So they boycotted coffee all over the US. The direct result of that in Brazil was people lost their jobs, had no way of feeding their families - a disaster caused by well-meaning people wanting to help. There are other cases. For a while in China, textile factories were closed because workers were being exploited. But these were people's jobs. Yes, they were being mistreated. Alternatively, without that work, they had nothing. This is where it gets difficult. We have to talk with people and change conditions on the ground. Not just say, "We are going to boycott such and such." This includes the ecological perspective. You can't try to solve one problem and say to hell with everything that happens around it. Try to understand the greater whole, otherwise there will be unintended consequences.

\section{Sometimes while caring for others, some people, often women, sacrifice so much they lose their sense of self-worth, sometimes jeopardizing their health.}

Right. When some of us started writing about care ethics, that was the big worry for many feminists. We may be past that now because people recognize the difference between caring and care giving. Caring is a moral way of life in the world, while care giving can be done with or without caring. The prime example is Nurse Ratched in One Flew Over the Cuckoo's Nest. Her job was care giver but she was not a caring person. She was awful. Here's why I find Martin Buber helpful. In a mutual relation, people regularly change positions. I'm the one-who-cares and he's the one-cared-for. Then we switch and I'm cared for. These are not permanent labels. It's dynamic. The word is better used to describe the relation rather than the person, which isn't to deny that still in this country, women do most of the care giving. But that can change over time. 
Thank you for clarifying the difference between caring for and caring about.

The last part of The Maternal Factor is concerned with caring about, caring for and the care driven theory of justice. Instead of putting them opposite each other, it is looking at how they could be combined.

You have continuously supported the Ikeda Center, especially the Education Fellows Program, which provides grants for doctoral students. Initially we asked if using "Soka Education" was too narrow. You said, "Why not? Go ahead." How do you explain Soka Education?

I talk about commonalities between Makiguchi and Dewey, then ask for questions when it comes to details. By and large, people are open and interested. The concept of value creation can be difficult. To appreciate others' values is even more difficult. How do the two go together? I don't see a problem with promoting Soka Education as long as it is not done in an authoritarian way. If you were to say, "We are here to save the world and your souls," I would be out the door going in another direction!

From the beginning, Makiguchi set a clear tone. He encouraged students to think critically, asking, "What is education for?" Especially during wartime Japan, many teachers believed the purpose of education was to develop citizens to support the nation. In contrast, Makiguchi believed the aim of education is the happiness of the children.

Then the question arises, "What is happiness?" In teaching, you are not going to tell students what happiness is. You will help them explore what people have said about it, what they feel about it. My book Happiness and Education (2003) has been translated into more languages than any of my other books.

\section{April 24, 2016}

\section{Please share updates with your work on care ethics.}

Some interesting work is going on. Dan Engster has a new book out on caring and justice (Care Ethics and Political Theory, edited by Daniel Engster and Maurice Hamington, 2015). Stephanie Collins' book came out a year ago (The Core of Care Ethics, 2015). I'm concerned about listing principles and rules. This can sort of take the heart out. In writing on a theory of justice and political liberalism some years ago, John Rawls contrasted ideal theories and non-ideal theories. His of course is the so-called ideal theory, because it starts the way a mathematical theorem would, with postulates, definitions, rules and builds from there. 
Non-ideal theories are the sort John Dewey worked with. Dewey even spoke against ideal theories. His thinking was, don't make things up. Rather you have to start with situations, what matters right in front of you. That has always seemed right to me. Care theory is definitely a non-ideal theory in the Deweyan tradition. You start with what's right in front of you and work from there. You've got these two things going on now in care ethics, both interesting but very different.

In March, 2011 there was a huge earthquake and tsunami in Japan. Recently another big earthquake occurred in southern Japan. Naturally, individuals sincerely wanting to offer aid came from all over the country to help those suffering in the earthquake's aftermath. But so many came into the area, the locals responding to the disaster were overwhelmed with providing support for these volunteers. Some volunteers lacked common sense and didn't bring their own supplies. At the very least, they should bring their own blankets. Would you please comment?

You are pointing to a much bigger problem. Too often helpers are at the political level. Liberators will go in, tell the victims and the oppressed what they need, what they should be doing. They don't ask, they don't work with them. They prescribe for them. In this country, this breakdown in communications across social classes is dramatic. When so-called elites, those who are better off, want to do the right thing - often times they don't - but when they do, they think they know what the right thing is. They tell the other people. This causes an increase in racial problems. I was just writing about this with regard to the Black Lives Matter movement. People shout back, "All lives matter!" Of course, all lives matter. But they misunderstand what Black Lives Matter is all about. It's not about maintaining their lives. It's about restoring dignity and identity. All of that goes right over the heads of most white elite helpers.

You've touched on a current, local problem in Japan, but it is part of a bigger problem. To appear on the scene and say, "I'm here to help you," meaning "I'm in good shape and you are in bad shape" and not even ask, "What can I do? Tell me what you need? Tell me what we should do together?" This is among the biggest moral social problems we have in the world. In the US right now, it's worse, more acute than I've ever seen. You see that in how so many have embraced Donald Trump. These people have suffered for years, no pay raises, less money to spend, less attention on the public level.

In a recent magazine article, a black woman running a social political organization describes what she is going through, saying San Francisco has broken her heart over and over. She works hard in her community. Supposedly sympathetic people come to her, feeling they have a right to tell the black residents there what to do, even though they've never lived there nor in those conditions. She is totally frustrated. I'm guessing this is going on all over the world but certainly in this country. 


\section{People think they understand care but they really don't know what it is.}

No, they don't.

\section{In terms of the family and schools, how do you educate people about care?}

We have to keep trying. I remind people there is a difference between caring and professional care giving because some care givers are not caring. They can be mean. You have to get that distinction across. Then there is caring-about and caring-for. Caring-about is just concern. You can care about, maybe give five bucks and you don't do anything else. Caring-for is a direct relationship. This has to be made clear before going on to problems caring can help with.

We need to learn and practice how to care. Ideally, the first place to learn and practice care is in the family. How did you unite a family with ten children, five biological and five adopted?

Neither Jim nor I ever really understood what happened there. It's the kids who did it. In all those years, I never saw a sibling argument or a complaint across natural versus adopted lines. And the adopted kids contributed to a deeper respect for parents. I remember when one of the boys was fairly new to the family. The kids were playing cards one night. They were supposed to be going to bed. That night they got into an argument. I happened to overhear part of it. The adopted boy was shouting at his brother, saying, "Don't talk like that about him. He is your father!" They all went silent. Here is a Korean-American kid who had all his life longed for a father. Now he finally had one and he wasn't going to have his brother say anything bad about his father. It almost brings tears to my eyes to remember. To think how many kids there are in this world who are longing for a father or a mother. Heavens knows we had almost every other kind of problem with those kids, but we never had any battles across those lines. Those types of problem are more often produced by the parents than by the kids.

\section{Among the five adopted children, maybe they came into your family feeling} abandoned. Do you think they already had some kind of spiritual scar?

Well, they were all different ages. Three of them were Korean-American. Among them, one was 14 when he joined the family - the one who said, "He is your father!" Another family had brought him to this country. He had been with them for a year or so when they decided they didn't want him because he wasn't college material. Can you believe that? This is the dearest, most honest, generous kid you'd ever meet and he was rejected because he wasn't college material.

We found out his biological mother had another child. She had agreed to give up the new baby, provided he went to the same home where the brother was. What could 
we say? He was just a little over a year old when we got him. In between was the first child we adopted through Welcome House. He was almost six when we adopted him.

We never formally adopted the two others who were not Korean-American, but they still are considered part of the family. Their mothers didn't want to give them up but didn't want to take care of them either. A big job was helping those kids mend things and have decent relationships with their mothers, even though they weren't going to live with them. Our approach was different from wanting the child all to ourselves.

\section{It was important for you to gather the family together for the dinner each evening. What did you learn from having meals together? What was your primary concern?}

Jim Comer (James P. Comer, MD, Maurice Falk Professor of Child Psychiatry, Yale School of Medicine), the black psychologist, has written quite eloquently on this, describing his own family life and what dinner time meant. It wasn't just eating and filling yourself up. It was learning how to carry on a conversation. Everyone at the table got a chance to talk. They learned not to talk too long, not to interrupt each other, all the manners. This needs to be talked about more because many kids today don't have conversations in their families. They eat to satisfy their physical appetites and there is no real conversation.

In our family, it was taken for granted you would be there. If you didn't show up, we would ask, "Why? Where have you been?" We never forced them to eat any one thing. We would try to balance the meal, so there would be something each one liked to eat. We learned that the hard way, like most parents. With our first son, we thought, "He has to eat his vegetables!" We insisted he eat his peas. He would put some in his mouth and say, "Blech!" It wasn't worth it. To this day, he's in his fifties now, he doesn't eat peas. All parents have to learn these things. We learned that one pretty quickly. We would pass all the dishes around and people would take whatever they want.

Jim was a wonderful father. About once a week he would have a family meeting of sorts at the dinner table. There might be an agenda, such as what movies the kids wanted to see, where we might go on our next road trip and of course, how to apportion the duties. We always had a list. Jim would pass it around and the kids would sign up for what they would do. The list would come back to Jim and he would say, "Well, there are a few jobs here nobody signed up for. I guess that's because nobody likes these jobs. So, l'll pay something on these jobs."

It was understood everybody had to contribute to the family and you didn't get paid for that. But here are chores nobody wants, and Jim offers to pay so much for this job and so much for that job. We would pass the list around again. Sometimes we'd have to say no if a particular kid was too young but wanted the job, "Well maybe next year for you on that." See how wise that was? We found out the work they didn't like and why shouldn't you pay for that? If you hired somebody, you would have to pay. 
One night, Jim asked, "How many of you kids have been on a train?" There were several who had never been on a train, for whatever reason. "Well, we've got to do something about that! We're going into New York City tonight!" He had already planned we would go to Madison Square Garden. I knew ahead too, because we had to clean up and rush off to catch the train.

Please share more about your willingness for your adopted children to meet their biological families.

Two of the girls had living mothers. We felt it was our responsibility to help them develop a better relationship with their biological mothers. We did pretty well. They never lived again with their mothers but they did visit them. This was a different responsibility from those kids formally adopted. But even the oldest Korean American boy wanted to and did visit his biological mother. He and his baby brother decided they would both go to Korea, once the brother wasn't a baby anymore. I guess the trip was fun but it was also a fiasco. The younger boy, a huge guy, felt so out of place in Korea. He enjoyed the visit but after he came home, he said he felt totally out of place there and never wanted to go back. We did our best to encourage decent relationships. You don't want to separate them from their original identity. Actually, they separate themselves. The less you try to make kids into your own things, the closer they get to you naturally.

Please share your thoughts on caring for students. You have written this means we don't treat students as objects and the student is always more important than any lessons being taught. One time you assigned a project and a student failed to turn in the assignment by the due date. You spoke with the student and waited until she finished the project.

Yes, sometimes that was the case. There are so many obvious things we could do better in schools. We are in terrible shape now with all the testing and suspending kids for small offenses. When Jim and I were in high school, I only remember in those four years one student ever being suspended, because he pricked the girl next to him with a pen knife. Of course, you don't do that sort of thing and he was suspended. Now kids are suspended for being late three times. What are we accomplishing when we do something like that? We are giving them a legal excuse for not coming to school.

Everything is by the rule now, with teachers required to have a learning objective written up on the board for every day. On most days you do have one. I was a math teacher and I knew when I was going to teach quadratic equations on a particular day. But there are some days when you should drop that objective and talk about what concerns the kids. Find a way to bring that in.

Just the other day I was talking with someone concerned we're not teaching as much literature in English classes now because the Common Core suggests greater 
emphasis on reading articles and documents and less on literature. There's all this worry about loss of literature. I suggested why don't we all pitch in together and make sure in all the other subjects we do something in literature. I came up with ideas for math. You could include some literature in every subject. You don't have to lose literature, just spread it out. People think too narrowly because every discipline is sharply separated from every other discipline.

Fundamental to care theory is that it's relational. It's not a virtue ethic in the sense you look only at the agent's character, what the agent does. You have to look at the relationship because both contribute to it. The one-caring and the one-cared-for, both contribute significantly to a caring relation. Quite a few people now in many organizations are talking about it. But there is this worrisome trend, where they want to formalize it. That is dangerous, because you have to stay open.

Today people are becoming isolated and indifferent to one another. It can be difficult to develop real care. We have to learn how to engage in dialogue and listen. Would you please share your thoughts on the practice of listening?

I'm reminded of Bob Putman. His book Bowling Alone: The Collapse and Revival of American Community (2000), was popular years ago, and his latest book is Our Kids: The American Dream in Crisis (2015). A subtheme is the lack of communication across social lines. Bob describes where he grew up, Port Clinton, Ohio, near Lake Erie as having fairly rich people and fairly poor people and a lot of other people. Reading that, I thought that's how it was when I was a kid. We lived in a town with people who had quite a substantial amount of money and people who had nothing and everybody in between. In those days, all of these people knew each other or at least could recognize each other on the street and say, "Good morning," because they met in the butcher shop, the doctor's office, at the school and in church. When he went back to his hometown, the wealthier people now live in a gated community, right on the lake. For the most part, they never talk to other people in the town. That's a dramatic change and we're seeing the effects in this present election period, a sense of being left out, ignored.

With regard to developing a sense of care for the natural world, we have the example of Rachel Carson, who observed the outdoors together with her nephew. She was not trying to teach so much as observing together, naturally developing a sense of wonder. How did you share and experience the outdoors with your children? How did they learn to be in nature and together with other people?

The basic idea again is to maintain the relational aspect. You don't take children out and say you are going to learn the following ten things. Rather, you walk together, explore together, listen to them. I don't know why that is so hard for parents these 
days, who seem to think they have always to be directing their kids. It's a desperation of sorts. The emphasis is on how you and I get along with one another. It's not whether you do what I tell you because it's better for you if you do what I tell you. First you listen. Even people you are not very fond of are sometimes right. You can't take sides and then stay on that side regardless of how stupid it is. It's part of what you learn raising a large family too. Kids have differences. Sometimes it takes a long time.

\section{Thank you.}

